\title{
Discussion and Research on Audit Internal Control and Practice Construction Based on Risk Management
}

\author{
Wenquan Shi \\ Faculty of Economics and Management, Suzhou Polytechnic Institute of Agriculture, Suzhou, China \\ E-mail: wxshiwq@aliyun.com
}

\begin{abstract}
With the rapid development of the market economy in China, how to strengthen audit risk management and enable enterprises to improve the internal audit control system to cope with complex and severe market risks has become the focus of current social concern. In foreign countries, although audit internal control and risk management-based practice construction are relatively mature, China's construction of a risk-oriented internal audit control system has just begun, and needs to be further improved. Therefore, strengthening audit internal control and practice construction based on risk management is urgent for Chinese enterprises. This article starts with the connotation of internal audit control and risk management, expounds the relationship between risk management and internal audit control, and discusses the internal control of audit and practice construction based on risk management. In addition, it also analyzes the current situation of China's construction, and puts forward practical countermeasures to strengthen the internal control of China's corporate auditing.
\end{abstract}

Keywords: risk management, internal audit control, financial internal control

\section{Introduction}

The market economy in China is develping rapidly, so how to strengthen audit risk management and enable enterprises to improve the internal audit control system to cope with complex and severe market risks has become the focus of current social concern. Recently China's construction of a risk-oriented internal audit control system has just begun, and needs to be further improved. Therefore, strengthening audit internal control and practice construction based on risk management is urgent for Chinese enterprises. This article expounds the relationship between risk management and internal audit control, and discusses the internal control of audit and practice construction based on risk management. ${ }^{[1]}$ In addition, it also analyzes the current situation of China's construction, and puts forward practical countermeasures to strengthen the internal control of China's corporate auditing.

\section{Connotation of internal audit control}

Internal audit control is a process designed and implemented by an organization to achieve the objective of providing reasonable assurance for achieving the organization's goals. The assurance provided by the internal audit control is: the effective execution of economic activities; the safety and integrity of the organization's property; the provision of complete and true financial statements to the outside; the assurance that enterprises can prevent, detect and correct fraud and errors. Internal audit control is implemented by the company's board of directors, managers, board of supervisors, and all employees of the company. The purpose is a management process to achieve the company's control objectives. The internal audit control of an enterprise is affected by factors such as the nature of the enterprise, management level, and systems. This leads to the development of internal audit control depending on economic progress and social development. ${ }^{[2]}$

\section{Connotation of risk management}

Enterprise risk management is a process of enterprise management. Risk management is jointly implemented by the board of directors, management and other personnel of the enterprise, and management is applied to the formulation of the company's strategy. The purpose is to identify potential issues that may affect the enterprise, manage the enterprise's risk, limit the risk to the enterprise's risk capacity, and provide an effective guarantee for the enterprise to achieve its goals. 


\section{Links between internal audit control and risk management}

At present, internal audit control and risk management generally have the following relations: internal audit control is an effective part of risk management; internal audit control includes risk management; there is an equivalent relationship between risk management and internal audit control. Based on the impact of changes in the economic environment on enterprises, this paper dialectically analyzes the relationship between internal audit control and risk management.

\subsection{Differences between internal audit control and risk management}

In the early stage of economic development, risk management was in the traditional risk management stage, and internal audit control was also in the overall framework of internal audit control. Risk management and internal audit control were independent of each other. During this period, internal audit control served as a corporate restraint system to effectively prevent potential risks that may affect corporate interests and economic goals, in order to achieve the purpose of protecting corporate assets. Internal audit control focuses more on the control of financial information, but does not pay attention to non-financial information such as changes in the external macro environment of the enterprise. During this period, internal audit controls and audits could only prevent risks, but not diversify corporate risks. Due to the continuous development of the market economy and the increasingly fierce market competition, the development environment of enterprises has become complicated and changeable. The risk management of enterprises has received more and more attention from enterprise managers and operators. Enterprise risk management is the analysis and judgment of enterprises on their own uncertain factors in development and operation. In the stage of traditional risk management, the enterprise's risk management only focuses on some pure risks, such as the factors of natural disasters. Risk management also serves the purpose of reducing substantial losses. Therefore, in the initial stage of enterprise development, the focus of internal audit control and risk management is different, which are two different and independent management directions in the enterprise.

\subsection{The integration of internal audit control and risk management}

With the development of market economy and economic technology, internal audit control and risk management are gradually integrated and unified. Enterprises have put forward new requirements for controlling risk factors in their own operations and grasping opportunities in competition. At the same time, they have also put forward new requirements for the analysis and judgment of risks and opportunities in risk management. The internal audit control of the enterprise has entered the overall framework system, and risk management requires not only to avoid risks, but also to control the preservation and appreciation of the assets of the enterprise and control the development opportunities in the enterprise's operating process. The operator of an enterprise must not only grasp the opportunity in the process of operation, but also pay attention to the risks brought by the opportunity. This requires the operator of the enterprise to control the risks brought by it while grasping the development opportunity. Therefore, internal audit control and risk management are gradually integrated and unified in the mature stage of an enterprise's development.

\subsection{Division of internal audit control and risk management}

Risk management and internal audit control should be unified and integrated. The combined part mainly consists of management and control analysis methods and some specific measures. Internal audit control and risk management must be divided in principle in order to reflect the essence of internal audit control and risk management, determine the goals of the enterprise, clear the way to solve problems and risks, and improve the efficiency of enterprise management. Depending on the content of the risk, its different types can be managed. Routine risks are included in internal audit control; nonconventional risks, within the scope of internal audit control, must implement methods for handling unconventional events to reduce risks to acceptable levels. For some uncertain events, they need to be included in the scope of risk management to make up for the lack of internal audit control. In actual business operations, a large number of mixed events are often encountered. This requires converting these events into regular events as much as possible in order to be included in the scope of internal audit control. Therefore, full consideration must be given to the scope of internal audit control to prevent and control the occurrence of such incidents, and to develop methods to resolve such incidents. The division of the enterprise's risk management and internal audit control has played a role in strengthening the pertinence of enterprise management and improving the efficiency of enterprise management. The essence of internal audit control is the management of relatively stable operations, focusing on achieving the management objectives of the enterprise through means of control. The essence of risk management is to make judgments and decisions on more specific operating events and uncertain factors to maximize the benefits brought by risks and opportunities. The key to dividing the two is to include uncertain and sudden factors in the operation of the enterprise into the category of risk management, and to include issues with certain continuity and stability into the category of internal audit control. In this way, the company's operations are 
controlled by a combination of internal audit control and risk management to achieve the goals of enterprise management. An effective internal audit control system can only achieve comprehensive and scientific enterprise management, not an absolute guarantee for the company to achieve its business objectives, and the important content of risk management is to make decisions and deal with measures after risks occur. Internal audit control and risk management complement each other so that companies can seize opportunities, avoid risks, and achieve their business goals.

\section{Internal audit control based on risk management}

Audit internal control based on risk management is to further develop and improve by combining the methods and characteristics of internal audit control with the enterprise's risk management. Risk management is the analysis and judgment of uncertain factors in the development and operation of the enterprise, and at the same time, decisions are made on more stable events in the operation to reduce the risk to an acceptable level. In the lower risk category, grasp Opportunities for the development of enterprises to maximize their benefits. Incorporating the construction of the company's internal audit control into the enterprise's risk management essentially guarantees the effectiveness of the company's internal audit control and the healthy development of the company. The internal audit control of an enterprise is an activity by which the internal audit department performs audit supervision on the effectiveness, completeness, and soundness of the internal control of the financial management of the enterprise in accordance with the relevant national laws and regulations. Through the enterprise's risk management, it is possible to analyze and judge the financial risks of the enterprise, so that the internal audit control of the enterprise can be carried out in a relatively stable financial environment. The internal audit control can improve the financial management of the enterprise, and improve the level of financial management And work efficiency.

Auditing internal control requires enterprise management to judge the company's operating activities based on management experience and relevant knowledge. Therefore, there is a risk of auditing internal control due to serious economic consequences caused by errors in judgment. The quality of internal audit control refers to the quality of the internal audit control and its results. Internal audit control is the main condition for the survival and development of an enterprise. The quality of its control is related to the role of internal audit control and the future development of the enterprise. The internal audit quality control refers to the management department of an enterprise's internal audit work to supervise, coordinate and comprehensively manage the specific content and scope of the internal audit work.

There is a dialectical relationship between an enterprise's risk management and its internal audit control. By using various methods and methods of risk management, the risks of internal audit can be effectively controlled and reduced, and the quality of internal audit control can be improved. ${ }^{[3]}$ In addition, the higher the quality of the internal audit control, the less risk the enterprise faces. The improvement in the quality of internal audit control shows that the company's financial staff has adopted appropriate audit procedures to ensure that the financial staff should be cautious and standardized, and made accurate judgments on the company's financial matters. And the lower the quality of audit internal control, the greater the risk the enterprise faces.

\section{Strengthening the practice of auditing internal control in Chinese enterprises}

Due to the rapid development of China's market economy, how to build an audit internal control system and method based on risk management and strengthen the internal audit control of Chinese enterprises' finances are urgent issues that need to be resolved.

Before implementing specific audit internal control, enterprises must first be familiar with and understand the laws and regulations related to audit internal control of corporate business matters and relevant national policies. On the basis of fully understanding the situation of the audit internal control department, according to the purpose of audit internal control, Determine the scope and focus of operations for internal audit control. Secondly, we must prepare a rigorous internal audit control plan, pay attention to the application of important principles in internal audit work, and make a preliminary evaluation of the internal audit control system on the premise of understanding the basic situation of the enterprise department. ${ }^{[8]}$ At the same time, It is necessary to identify the audit risk of the enterprise, recognize the risk and find out the possible risk points, analyze the various factors that may cause the risk, evaluate the risk management system, analyze the possibility of the risk and the quality of the internal audit control work. The extent of the possible impact. Then, according to the results of the enterprise risk assessment, risk response measures should be formulated to avoid risks to the greatest extent and reduce business activities that bring the possibility of risks to the enterprise. ${ }^{[4]}$

Relevant institutions of internal audit control of enterprises shall establish and improve various management rules and 
regulations, and implement management in strict accordance with regulations. The internal audit control department shall strictly implement the hierarchical review system for internal audit control work in order to reduce and eliminate artificial audit errors. Management personnel shall timely discover and resolve audit problems encountered in the process of internal audit control, ensure the smooth progress of internal audit control, and reduce the management risk of the enterprise. ${ }^{[9]}$

The risk management of an enterprise's internal audit control mainly comes from its own financial and operating risks. Therefore, the audit internal control personnel shall cooperate with the management of the enterprise to carry out risk control and risk management of the enterprise, and at the same time, it shall establish a risk assessment mechanism adapted to the enterprise to reduce the risk of the internal audit of the enterprise. Risk assessment refers to the risk evaluation of the results of the implementation of the scheme under the expected state of the enterprise in combination with the company's major operating decisions. In the process of risk assessment, we should pay attention to the enterprise management, the nature of the risks that the enterprise may face and the strength of the risks, so that the management of the enterprise can take corresponding decisions to achieve the purpose of avoiding and reducing risks. ${ }^{[5]}$ Establish an enterprise risk assessment mechanism. The relevant audit internal control personnel must fully communicate with the management of the enterprise to determine the nature, size and scope of the risk according to the company's operating conditions, strategic rules, decision objectives and future business operations. From this, the scope of internal audit control is determined, and the target of the key audit and the audit method is adopted. ${ }^{[7]}$ In addition, the enterprise shall collect relevant information on financial risks and operating risks, determine the profile of enterprise project risks, and at the same time, shall formulate an annual audit work plan for the enterprise and submit it for approval. Finally, at the stage of concrete implementation of the project, it is necessary to evaluate the risks and the results of risk control that may occur during project implementation, and to put forward effective suggestions that are conducive to risk management.

\section{Conclusion}

The internal audit control and risk management of an enterprise cannot be completely replaced. The scope of internal audit control is the daily business affairs. In order to achieve the systematic guarantee of business objectives, the risk prevention can only be carried out within a certain range, and risk management is the management of the occurrence of risks, which is a special procedure in the business process. Internal audit control based on risk management is an important development of the internal control of corporate financial management. Only by combining internal audit control and corporate risk management, can the company's finance be effectively and safely managed. Therefore, enterprises and institutions should establish and improve internal control systems to reduce the risk of decision-making to acceptable levels. ${ }^{[6]}$ By understanding the connection and difference between internal audit control and risk management, internal audit can deal with different methods and procedures according to the different objectives of the division, so that the internal audit control and the special project for risk management are conducted jointly.

\section{References}

[1] Wang Jingxuan. Research on internal control system based on financial risk management. Economic and trade practice. 2018; (01).

[2] Lu Qingfeng. Response analysis of internal control to the development of organizational behavior theory. Chief accountant of China. 2012; (02).

[3] Hu Huiqin. Analysis based on the control of enterprise internal audit risk. Science and technology plaza. 2006; (03).

[4] Li Zhenxing. Analysis on financial management innovation measures of real estate enterprises operators. 2014; (06).

[5] Yuan Jie. Exploration on internal control of construction enterprises. Financial sector. 2013; (11).

[6] Lin Sihan. Research on risk management audit of telecom industry--a case study of China telecom jiangsu company. Zhejiang gongshang University. 2017; (12).

[7] Chen Zhaohui. Internal audit quality control and analysis based on risk management. Journal of agricultural bank of China whan training college. 2014; (2).

[8] Xu Yeqing. On the problems and countermeasures of internal audit of state-owned enterprises. Finance and economics (academic edition). 2013; (6)

[9] Yang Xiaomin. Problems and countermeasures of internal audit of state-owned enterprises. Market weekly. (theoretical research). 2014; (1) 